\title{
Disease-Reducing Effect of Chromolaena odorata Extract on Sheath Blight and Other Rice Diseases
}

\author{
Nguyễn Đắc Khoa, Phan Thị Hồng Thúy, Trần Thị Thu Thủy, David B. Collinge, and Hans Jørgen Lyngs Jørgensen
}

First, fourth, and fifth authors: Department of Plant Biology and Biotechnology, Faculty of Life Sciences, University of Copenhagen, Thorvaldsensvej 40, 1871 Frederiksberg C, Denmark; and first, second, and third authors: Department of Plant Protection, College of Agriculture and Applied Biology, Can Tho University, 3/2 Street, Ninh Kieu District, Can Tho City, Vietnam.

Accepted for publication 1 September 2010.

\begin{abstract}
Khoa, N. D., Thuy, P. T. H., Thuy, T. T. T., Collinge, D. B., and Jørgensen, H. J. L. 2011. Disease-reducing effect of Chromolaena odorata extract on sheath blight and other rice diseases. Phytopathology 101:231-240.

Sheath blight caused by Rhizoctonia solani (teleomorph: Thanatephorus cucumeris) is a major cause of crop loss in intensive rice production systems. No economically viable control methods have been developed. We screened aqueous extracts of common herbal plants that could reduce sheath blight lesions and found that foliar spraying and seed

soaking application of extracts of either fresh or dried leaves of Chromolaena odorata gave up to $68 \%$ reduction in sheath blight lesion lengths under controlled and semi-field conditions. The observed reductions were not dependent on growth conditions of $C$. odorata and rice cultivar. The effect was observed until 21 days after inoculation and was not dependent on microbial activity. Under semi-field conditions, extracts also reduced severity of other important rice diseases, i.e., blast (Pyricularia oryzae) using foliar spray (up to 45\%), brown spot (Bipolaris oryzae) using seed treatment (up to 57\%), and bacterial blight (Xanthomonas oryzae pv. oryzae) using both application methods (up to $50 \%$ ).
\end{abstract}

Sheath blight caused by Rhizoctonia solani Kühn (teleomorph: Thanatephorus cucumeris) is a major cause of crop loss in intensive rice production systems, especially in tropical Asia $(23,45,58)$. The disease causes irregular greenish gray lesions with grayish white centers and brown margins on leaf sheaths of rice plants. The symptoms are usually first observed near the waterline in the field as the disease is spread by sclerotia of the pathogen through flowing water. Under favorable environmental conditions, symptoms are also observed on leaf laminae. The merging of several large lesions on a leaf sheath usually causes death of the whole leaf, and in severe cases, all leaves of a plant are blighted, causing plant collapse and subsequent death. No economically viable control methods have been developed to combat this pathogen. Chemical means of management are not particularly effective; they are also expensive and potentially harmful to ecosystems. In addition, no high levels of heritable resistance are available to control the disease (13).

Searches for natural sources of disease resistance genes have been performed in order to develop resistant cultivars to manage the disease $(16,17)$. No highly resistant cultivars have been produced through traditional breeding. With the development of genetic engineering techniques for rice, a number of resistance genes from other species have been used to produce transgenic resistant cultivars $(13,52,56)$. Such cultivars have been developed at the experimental level but have not been adopted in production since there are concerns with respect to the use of transgenic crops $(5,11,25)$. Indeed, transgenic crops may impose adverse impacts on the natural ecosystem through gene flow. For instance, there are founded concerns about rates of gene flow to weedy rice $(22,54,55)$. In addition, rapid pathogen adaptation to new sources

Corresponding author: N. D. Khoa; E-mail address: dkn@life.ku.dk and ndkhoa@ctu.edu.vn

doi:10.1094/PHYTO-04-10-0113

(C) 2011 The American Phytopathological Society of resistance may lead to a shift in pathogen populations and subsequently a "break down" of resistance, making the pathogen even more difficult to control $(36,38)$. Finally, the price for company-produced seeds for subsistence farmers in developing countries is high compared to locally produced or farm-saved seeds, thus reducing the incentive to purchase seeds.

Since the 1980s, the use of microbial antagonists has been viewed as an alternative strategy to control sheath blight $(21,39$, $59)$. This strategy is still being considered $(9,12,46)$. However, the release of large populations of living microorganisms into the environment, especially if they are genetically engineered, raises some important concerns. Firstly, introduced microorganisms could affect the indigenous microbial populations $(2,53)$. New pathogens of plants and even of humans could conceivably evolve due to horizontal gene transfer among microorganisms $(28,35$, 57). Secondly, the antagonistic microorganisms could easily become ineffective because pathogens are able to "counteract" the antagonists as suggested by Duffy et al. (15). Thirdly, farmers may face high costs to buy commercial products $(18,19)$. Finally, detailed knowledge is required to use the products effectively because the performance of antagonists varies considerably under different environmental conditions $(3,42,50)$. Another strategy for alternative disease control is to use induced resistance $(32,61)$, where it is the plant itself which combats the pathogen. A number of inducers which could trigger rice resistance against sheath blight have been identified, i.e., the chemical acibenzolar-Smethyl (49), a number of bacteria $(27,40,48)$, as well as a methanol leaf extract of Datura metel (29). The use of chemicals and living microorganisms to induce resistance against diseases may have the same potential disadvantages as those of the chemical pesticides and microbial antagonists. Even though the use of a methanol leaf extract from D. metel (29) is a possible control option, it would be cheaper and technically simpler for farmers to use an aqueous extract of a more common plant than $D$. metel.

In order to help subsistence farmers to control sheath blight in a cheap, simple, and eco-friendly way, we screened aqueous extracts of wild herbal plants in Vietnam for their ability to reduce 
infection of $R$. solani. Aqueous extracts made from nine common herbal plants, i.e., Azadirachta indica (fresh leaves and seeds), Kalanchoe pinnata (fresh leaves), Ageratum conyzoides (fresh leaves), Senna alata (fresh leaves), Datura metel (fresh leaves), Allium sativum (bulbs), Physalis angulata (fresh leaves), Eclipta prostrate (fresh leaves), and Chromolaena odorata (L.) R. M. King and H. Robinson (Eupatorium odoratum L.) (fresh leaves), were tested for their effects against the pathogen. The extract from $C$. odorata was found to be the most effective. $C$. odorata is a shrub, belonging to the family Asteraceae. It originates from the Neotropics and has spread to many tropical parts of the world (41). In Vietnam, it is considered an invasive weed. Nevertheless, aqueous fresh leaf extract of this plant is styptic and is used as a folk remedy to treat human skin wounds. In addition, it is used to treat acute dysentery and diarrhea of children and other human diseases such as colitis, bone pain, inflammation of teeth and gums, and some skin diseases $(6,7)$.

In this paper, we describe the effect of an aqueous extract of $C$. odorata on sheath blight and other important rice diseases including bacterial blight (Xanthomonas oryzae pv. oryzae), blast (Pyricularia oryzae), and brown spot (Bipolaris oryzae) under controlled (Denmark) and semi-field conditions (Vietnam) by different application methods (foliar spray and seed treatment).

\section{MATERIALS AND METHODS}

Rice cultivars and pathogen isolates. A preliminary experiment was carried out under greenhouse conditions $\left(28^{\circ} \mathrm{C}\right.$ and $60 \%$ relative humidity $[\mathrm{RH}]$ under natural daylight conditions, with supplementary light [E-Papillon, SON-T 600W]) in Denmark to select the most compatible rice- $R$. solani interaction among the nine rice cultivars selected from the collection of Can Tho University (CTU, Vietnam), i.e., VND95-20, OM1490, MTL250, IR50404, IR42, IR72, MTL83, MTL145, and OM4498, inoculated with five $R$. solani isolates (Rs1 to Rs5) collected from different locations in the Mekong Delta of Vietnam. Cultivar OM4498 and isolate Rs3 were selected for this study. In addition, cv. Tetep (from CTU) was included in one of the experiments. Cultivar OM4498 was also used for studies of the effect of $C$. odorata extract on brown spot, whereas cv. Jasmine 85 (from CTU) was used for studies involving blast and bacterial blight because it is more susceptible to these diseases than OM4498. Highly virulent isolates of B. oryzae (Bo5), P. oryzae (Po6), and $X$. oryzae pv. oryzae (Xoo10) from the pathogen collection of CTU were used in the experiments.

Preparation and application of $C$. odorata extract. For experiments carried out in Denmark, $C$. odorata was propagated and maintained in a greenhouse at $28^{\circ} \mathrm{C}$ and $60 \% \mathrm{RH}$ under natural daylight conditions, with supplementary light (E-Papillon, SON-T 600W). For experiments carried out in Vietnam, leaves were collected from plants grown outdoors at the CTU campus. Leaves in both countries were collected during late afternoon to ensure physiologically comparable tissue. Healthy, mature leaves of $C$. odorata were collected from the plants and leaf extracts were prepared at room temperature using sterile distilled water. The fresh leaves were rinsed, blotted dry, and subsequently ground thoroughly with a pestle and mortar. After soaking in sterile distilled water for $10 \mathrm{~min}$, leaf debris was removed by filtration through cheesecloth. In experiments using extract from dried leaves, fresh leaves were dried for 3 days in an oven at $40^{\circ} \mathrm{C}$ before grinding. The dried leaves were also ground thoroughly and soaked in sterile distilled water overnight at $4^{\circ} \mathrm{C}$. All extracts were used immediately or stored at $-80^{\circ} \mathrm{C}$.

For seed treatment, rice seeds were soaked in the extract for $24 \mathrm{~h}$. Subsequently, the seeds were germinated on wet filter papers at $28^{\circ} \mathrm{C}$ for 2 days before sowing (DBS). For foliar spray application, $10 \mathrm{ml}$ of the plant extract was sprayed on the leaf laminas of each rice plant.
Experimental conditions. Controlled conditions. Experiments were conducted at University of Copenhagen, Denmark. Rice plants were grown in a greenhouse at $28^{\circ} \mathrm{C}$ and $60 \% \mathrm{RH}$ under natural daylight conditions, with supplementary light (E-Papillon, SON-T $600 \mathrm{~W})$. Each plant grew in a round pot $(8 \times 10 \mathrm{~cm})$ containing $120 \mathrm{~g}$ of a soil mixture composed of Pindstrup soil No. 2 (Pindstrup Mosebrug A/S, Denmark) and Sorbix vermiculite (Damolin A/S, Denmark) (4:1, vol/vol). Plants were watered with distilled water daily.

Semi-field conditions. Experiments were conducted outdoors under open sky with no shading and natural weather conditions at CTU located in the Mekong Delta of Vietnam. Rice plants were grown during the wet seasons of 2008 and 2009. Four plants grew in a round pot $(30 \times 30 \mathrm{~cm})$ containing $3 \mathrm{~kg}$ of local alluvial field soil. Water was applied to the pots daily. For the experiments on sheath blight and bacterial blight, a quantity of $0.23 \mathrm{~g}$ of $\mathrm{N}$ (urea, Dam Phu My, Vietnam) was applied to each pot at 7, 15, 20, and 30 days after sowing (DAS). In addition, $0.14 \mathrm{~g}$ of $\mathrm{P}$ (super phosphate, Lam Thao Fertilizers and Chemicals JSC, Vietnam) and $0.02 \mathrm{~g}$ of $\mathrm{K}$ (potassium chloride, Vinacam JSC, Vietnam) were provided to each pot at 2 DBS and 7 DAS, respectively. For the experiments on blast, the same amounts of $\mathrm{N}, \mathrm{P}$, and $\mathrm{K}$ were applied, but at 2 DBS and 5, 8, and 11 DAS for N, 2 DBS for P, and 5 DAS for K. For the experiment on brown spot, $0.64 \mathrm{~g}$ of $\mathrm{N}$ was applied to each pot only at 12 DAS.

Inoculum preparation, inoculation and disease assessment. Sheath blight. $R$. solani was grown at $28^{\circ} \mathrm{C}$ on agar plates containing $10 \mathrm{ml}$ of potato dextrose agar (PDA; Scharlau Chemie S.A., Spain). A 5-mm mycelial disk from the actively growing zone of a 3-day-old culture was used to inoculate each rice plant. The mycelial disk was attached to leaf sheath of the main tiller of the rice plant (approximately $10 \mathrm{~mm}$ above the soil surface) using cotton wool and tape. Sterile distilled water was added to the cotton wool daily to maintain high humidity. Rice plants were inoculated 45 DAS. Sheath blight was assessed by measuring the actual lesion length on the inoculated tiller of each rice plant. Assessments were generally made 7 days after inoculation (DAI) and, in some cases, 14 and 21 DAI.

Bacterial blight. $X$. oryzae pv. oryzae was grown at $28^{\circ} \mathrm{C}$ on agar plates containing $20 \mathrm{ml}$ of modified Wakimoto's medium ( $20 \mathrm{~g}$ of sucrose, $5 \mathrm{~g}$ of peptone, $0.5 \mathrm{~g}$ of $\mathrm{Ca}\left(\mathrm{NO}_{3}\right)_{2} \times 4 \mathrm{H}_{2} \mathrm{O}, 1.82 \mathrm{~g}$ of $\mathrm{Na}_{2} \mathrm{HPO}_{4} \times 7 \mathrm{H}_{2} \mathrm{O}, 0.05 \mathrm{~g}$ of $\mathrm{FeSO}_{4} \times 7 \mathrm{H}_{2} \mathrm{O}$, and $18 \mathrm{~g}$ of Bacto agar per liter) (30). Inoculum was prepared by scraping a 48 - to 72-h-old bacterial culture with $10 \mathrm{ml}$ of sterile distilled water. The concentration of the bacterial suspension used to inoculate rice plants was about $10^{9}$ colony forming units $(\mathrm{CFU}) / \mathrm{ml}$. The fourth leaf (young fully expanded leaf) of each rice plant was inoculated by the clipping method at 35 DAS and the disease was assessed by measuring lesion length at 10, 20, and 30 DAI (31).

Blast. P. oryzae was grown at $28^{\circ} \mathrm{C}$ on plates containing $10 \mathrm{ml}$ of modified PDA (Scharlau Chemie S.A. to which was added $20 \%$ [wt/vol] extract of fresh rice leaves). Four-day-old cultures were placed under near UV light (cycles of $12 \mathrm{~h}$ light [Philips TLD 36W/08] and $12 \mathrm{~h}$ darkness) for 7 days to stimulate conidial formation. At $20 \mathrm{DAS}$, the leaves of each rice plant were sprayed with $3 \mathrm{ml}$ of inoculum suspension containing $5 \times 10^{4}$ conidia $/ \mathrm{ml}$ and $0.01 \%$ (vol/vol) Tween 20 (Merck Schuchardt OHG, Germany). After inoculation, the plants were incubated at $25^{\circ} \mathrm{C} / 98 \%$ $\mathrm{RH}$ in darkness for $24 \mathrm{~h}$ to facilitate infection. Subsequently, they were transferred back to semi-field conditions. Disease was assessed as percent infected leaf area on the fifth leaf of each plant at 7 and 14 DAI.

Brown spot. B. oryzae was grown at $28^{\circ} \mathrm{C}$ on plates containing $10 \mathrm{ml}$ of "reduced" PDA (13 g/liter). Three-day-old cultures were placed under near-UV light for 7 days to stimulate conidial formation. At $20 \mathrm{DAS}$, the leaves of each rice plant were sprayed with $3 \mathrm{ml}$ of inoculum suspension containing $2 \times 10^{4}$ conidia $/ \mathrm{ml}$ and $0.01 \%$ ( $\mathrm{vol} / \mathrm{vol})$ Tween 20 . After inoculation, the plants were 
incubated at $25^{\circ} \mathrm{C} / 98 \% \mathrm{RH}$ in darkness for $24 \mathrm{~h}$ to facilitate infection. Subsequently, they were transferred back to semi-field conditions. Disease was assessed as percent infected leaf area on the fifth leaf of each plant at 5, 10, and 15 DAI.

Experiments on sheath blight under controlled conditions. Foliar spraying. Initially, three concentrations (2.5, 5, and 10\% [wt/vol]) of $C$. odorata fresh leaf extract were tested, applied 7 days before inoculation (DBI) with $R$. solani. Sterile distilled water was used as a control. In addition to the extract of $C$. odorata grown in Denmark, extract made from plants grown in Vietnam (leaves brought to Denmark) were used to test the effect of plants from different growth conditions. Disease was assessed 7 DAI. Together with cv. OM4498, cv. Tetep (as susceptible as cv. OM4498 under experimental conditions in Denmark) was used to compare effect of the extract on different rice cultivars. After the preliminary tests, $10 \%$ fresh leaf extract was chosen for further studies. Different spraying time points $(3,5$, and $7 \mathrm{DBI})$ were tested to select the optimal time of application. Disease was assessed at 7, 14, and 21 DAI to determine how long the extract could reduce symptoms of the disease. Both filter-sterilized and nonsterilized extracts were used to test if the effect was dependent on microbial activity. The extracts were sterilized by Minisart filters (pore size: $0.2 \mu \mathrm{m}$, Sartorius AG, Germany).

Furthermore, Bion 50 (500 g/kg WG, Syngenta), at a concentration of $1,000 \mu \mathrm{g} / \mathrm{ml}$ (49) was tested as foliar sprays at 3, 5, 7, and 10 DBI under controlled conditions to include a disease-reducing control agent, which is known to induce resistance against sheath blight. Disease was assessed at 7, 14, and 21 DAI. Based on the positive results, Bion $50(1,000 \mu \mathrm{g} / \mathrm{ml})$, sprayed at $10 \mathrm{DBI}$, was used as a disease-reducing control under semi-field conditions.

Seed soaking. Initially, three concentrations of $C$. odorata fresh leaf extract $(2.5,5$, and $10 \%)$ were tested. Sterile distilled water was used as a control. Disease was assessed 7 DAI. After the preliminary test, lower concentrations $(0.5,1$, and $2 \%)$ were tested to determine the lowest concentration by which the extract would still give an effect. Disease was assessed at 7, 14, and 21 DAI to determine how long the extract could reduce symptoms of the disease. Both filter-sterilized and nonsterilized extracts were tested to verify whether the effect was dependent on microbial activity.

Experiments on sheath blight and other diseases under semi-field conditions. Foliar spraying. For sheath blight, three concentrations $(2.5,5$, and $10 \%)$ of $C$. odorata fresh leaf extract were tested, with application at 3, 5, and 7 DBI. The same test was made for $1,2.5$, and $5 \%$ dried leaf extract. For bacterial blight, four concentrations $(1,2.5,5$, and $10 \%)$ were tested, with application 5 DBI. Similarly, three concentrations (1, 2.5, and $5 \%$ ) were tested against blast and brown spot. Sterile distilled water was used as a control. Sheath blight was assessed at 7, 14, and 21 DAI, bacterial blight at 10, 20, and 30 DAI, blast at 7 and 14 DAI, and brown spot at 5, 10, and 15 DAI.

Seed soaking. For sheath blight, six concentrations $(0.5,1,2$, $2.5,5$, and $10 \%$ ) of $C$. odorata fresh leaf extract were tested. The same test was made for $1,2.5$, and $5 \%$ dried leaf extract. Four concentrations $(1,2.5,5$, and $10 \%)$ were tested against bacterial blight and three concentrations $(1,2.5$, and 5\%) against blast and brown spot. Sterile distilled water was used as a control. The disease assessment time points used for the foliar spray tests were also used here.

Tests for direct antimicrobial activity. Five-millimeter mycelial disks from actively growing 3-day-old PDA cultures of $R$. solani, $P$. oryzae, and $B$. oryzae were placed in the center of

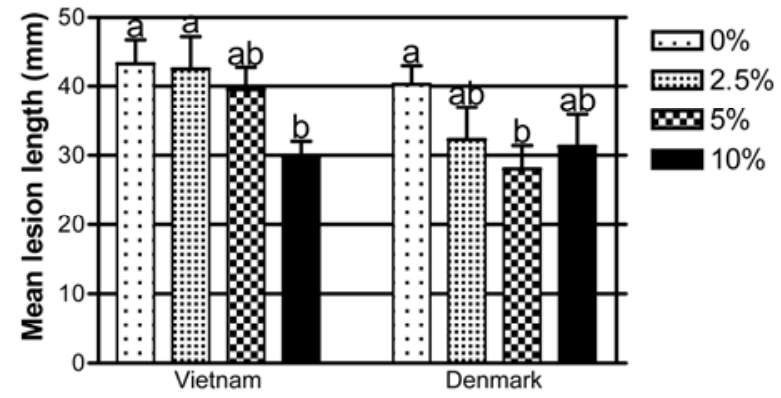

Growth conditions

A

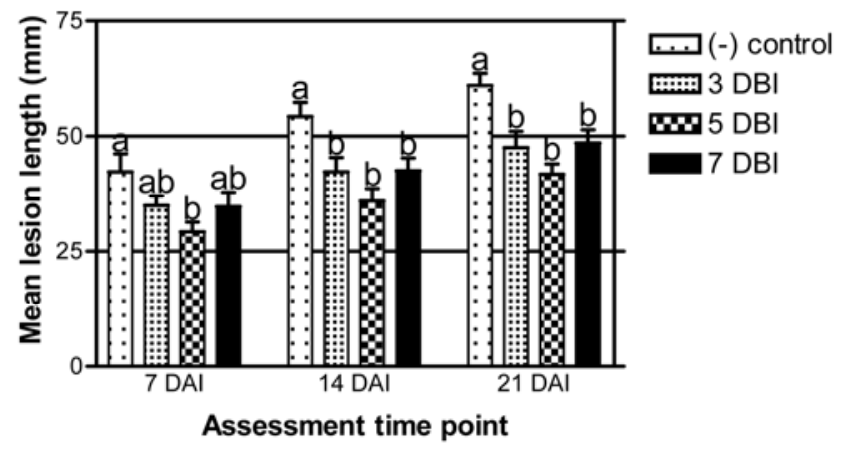

C
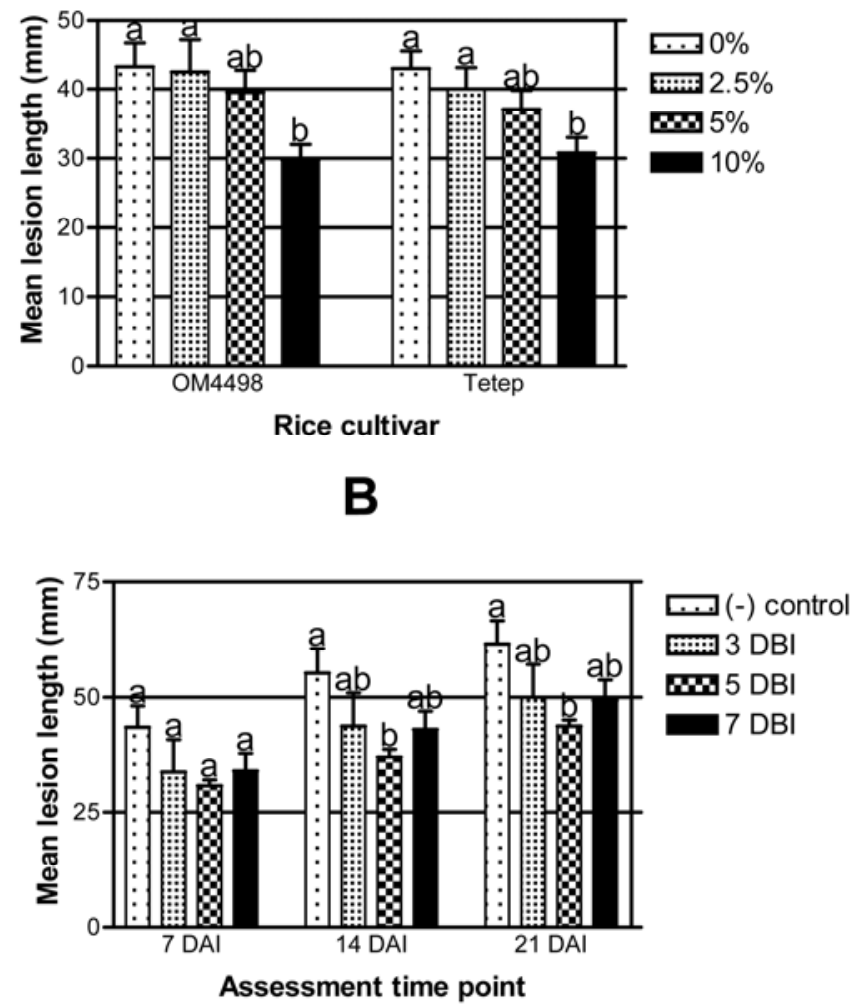

D

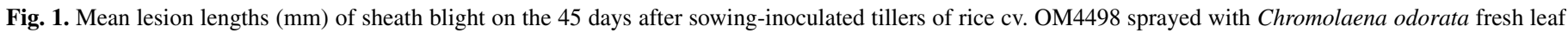

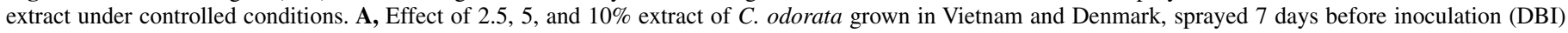

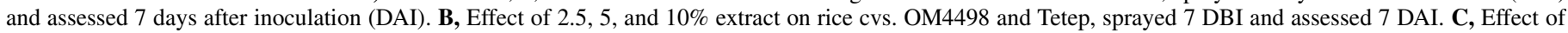

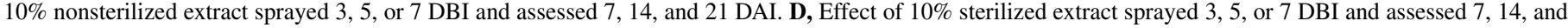

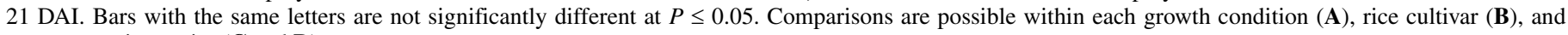
assessment time point ( $\mathbf{C}$ and $\mathbf{D})$. 
separate PDA plates. Five millimeter filter paper disks were soaked either in sterile distilled water, in 5 and $10 \%$ filtersterilized fresh leaf extract of $C$. odorata, or in the protein synthesis inhibitor cycloheximide at $400 \mu \mathrm{g} / \mathrm{ml}$ (ICN Biomedicals Inc.). These disks were placed in front of the actively growing mycelial tips of a 2-day-old culture of $R$. solani, a 7-day-old culture of $P$. oryzae, or a 5-day-old culture of B. oryzae. The plates
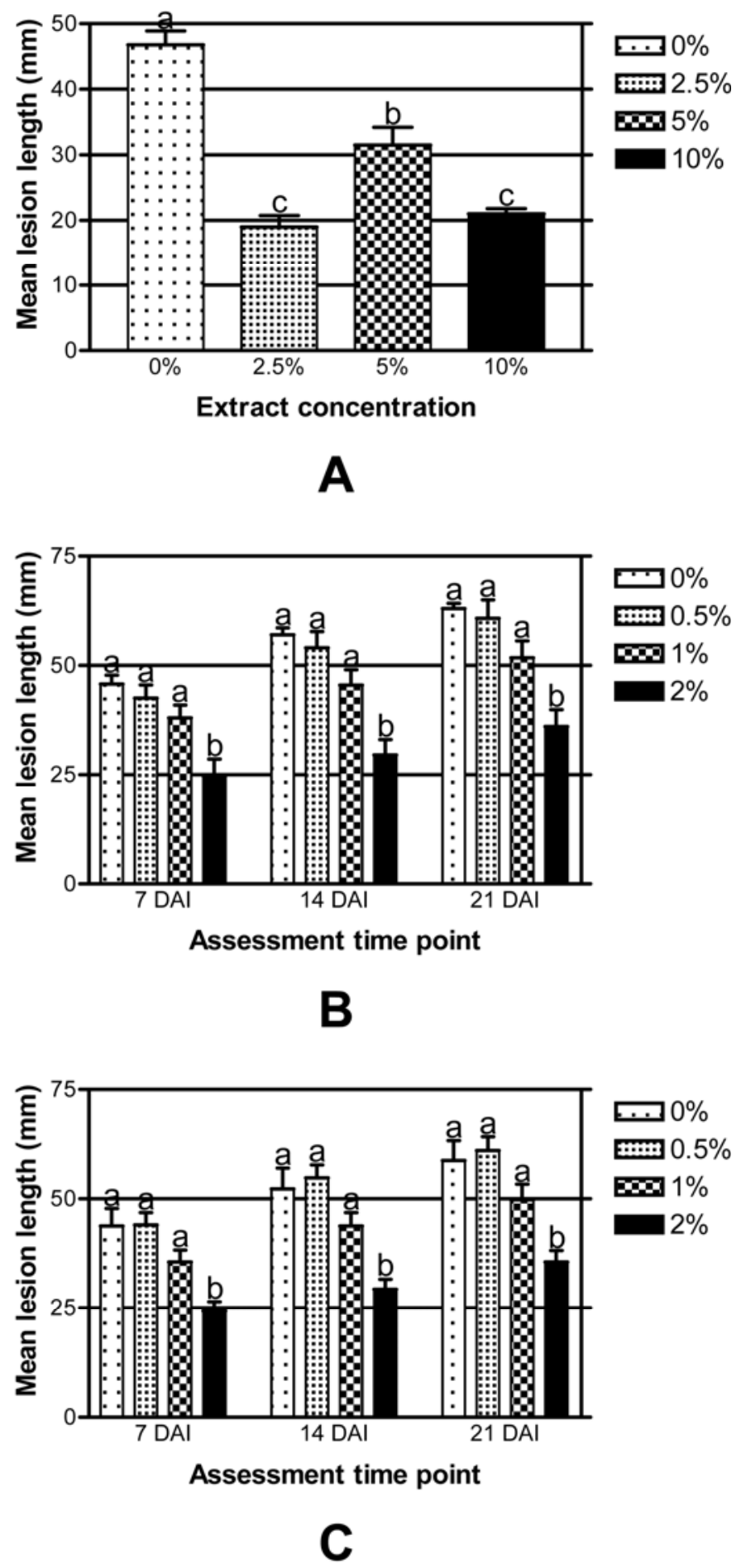

Fig. 2. Mean lesion lengths $(\mathrm{mm})$ of sheath blight on the 45 days after sowinginoculated tillers of rice cv. OM4498 under controlled conditions. The rice seeds were soaked in Chromolaena odorata fresh leaf extract. A, Effect of 2.5, 5 , and $10 \%$ extract assessed 7 days after inoculation (DAI). B, Effect of 0.5, 1, and $2 \%$ nonsterilized extract assessed 7,14 , and 21 DAI. C, Effect of $0.5,1$, and $2 \%$ sterilized extract assessed 7, 14, and 21 DAI. Bars with the same letters are not significantly different at $P \leq 0.05$. Comparisons are possible within each assessment time point. were incubated at $28^{\circ} \mathrm{C}$ in darkness. The presence of inhibition zones was recorded 3 days after placing the filter paper disks.

Conidial germination of $P$. oryzae and $B$. oryzae were investigated by incubating the conidia either in sterile distilled water in $10 \%$ filter-sterilized fresh leaf extract of $C$. odorata or in a fungicide control $(0.625 \mathrm{mg} / \mathrm{ml}$ Carbenzim $500 \mathrm{FL}$, Saigon Pesticide Company, Vietnam). Percentages of germinated conidia were recorded after incubating the conidia for 6 and $12 \mathrm{~h}$.

Cell vigor of $X$. oryzae pv. oryzae was studied by incubating the bacterial cells either in sterile distilled water, in $10 \%$ filtersterilized fresh leaf extract of $C$. odorata, or in $\mathrm{CuSO}_{4} \times 5 \mathrm{H}_{2} \mathrm{O}$ at $200 \mathrm{mg} / \mathrm{ml}$ (which has a bactericidal effect on $X$. oryzae pv. oryzae [20]) for $5 \mathrm{~min}$. Twenty milliliters of each suspension was plated on agar plates containing modified Wakimoto's medium. The plates were incubated at $28^{\circ} \mathrm{C}$ in darkness. Differences in the number of bacterial CFU were observed 3 days after plating.

Data analysis. In all experiments, each rice plant was considered as one experimental unit and each treatment had four replications. A similar design was applied in the tests for direct antimicrobial activity. All experiments were arranged in a randomized complete block design with four blocks and repeated at least twice. Representative results from individual experiments are presented.

Data from measurement of lesion lengths and infected leaf areas represent continuous variables and were therefore analyzed by analysis of variance assuming a normal distribution. Variances were stabilized by appropriate transformation of data if necessary. Data from conidial germination tests are assumed to follow a binomial distribution and were therefore analyzed by logistic regression (corrected for overdispersion when present) (10). All hypotheses were rejected at $P \leq 0.05$. Data were analyzed by PCSAS version 9.1 (SAS Institute Inc., Cary, NC). In the following, all differences are significant unless specifically mentioned.

\section{RESULTS}

Effect of $C$. odorata leaf extract on sheath blight. Foliar spraying under controlled conditions. Fresh leaf extracts of $C$. odorata grown in Vietnam and Denmark were used to verify the effect of plants under different growth conditions (Fig. 1A). Concentrations of $2.5,5$, and $10 \%$ of the extract were tested by spraying at $7 \mathrm{DBI}$. Mean lesion lengths were reduced compared with the control treatment using water at 7 DAI for $10 \%$ extract made from plants grown in Vietnam $(31 \%)$ and 5\% extract made from plants grown in Denmark (30\%). The effect was then verified in the two rice cultivars OM4498 and Tetep (Fig. 1B), using 2.5, 5, and $10 \%$ extract from plants grown in Vietnam. Reductions of mean lesion lengths compared with the control treatment were observed for the $10 \%$ extract in both cultivars ( $31 \%$ for cv. OM4498 and $29 \%$ for cv. Tetep). To find the optimal spraying time point and to study how long the extract could reduce symptoms of the disease, three spraying time points $(3,5$, and $7 \mathrm{DBI}$ ) were tested and the disease was assessed at 7, 14, and 21 DAI (Fig. 1C). Based on previous results, 10\% fresh leaf extract was chosen for this experiment. For the assessment at 7 DAI, only the spraying treatment at 5 DBI reduced mean lesion length (31\%) compared with the control, whereas all spray time points reduced it at 14 (up to $34 \%$ ) and 21 DAI (up to $32 \%$ ). There were no differences among the spraying time points. To test whether the disease-reducing effect was dependent on microbial activity, this experiment was also performed using filter-sterilized $10 \%$ extract (Fig. 1D). A disease-reducing effect was only observed for the 5 DBI treatment at $14(33 \%)$ and 21 DAI (29\%), but no differences were seen between nonsterilized and sterilized extract.

Seed soaking under controlled conditions. Initially, 2.5, 5, and $10 \%$ fresh leaf extract were tested (Fig. 2A). Reductions of mean lesion lengths (up to 59\%) were observed at 7 DAI for all treatments compared with the control. No effect of the extract was 
observed on seed germination and seedling development (data not shown). Subsequently, lower concentrations $(0.5,1$, and $2 \%)$ were tested to investigate how low concentrations would still give an effect, with disease assessments at 7, 14, and 21 DAI to study how long the extract could reduce symptoms of the disease (Fig. $2 \mathrm{~B})$. At all time points, the $2 \%$ treatment reduced mean lesion length compared with the control (46\% at 7 DAI, $48 \%$ at 14 DAI, and $43 \%$ at $21 \mathrm{DAI})$. To test whether the disease-reducing effect was dependent on microbial activity, 0.5, 1, and 2\% filtersterilized extract were used in the same experiment (Fig. 2C). Again, the $2 \%$ extract reduced the mean lesion length at all time points (45\% at $7 \mathrm{DAI}, 44 \%$ at $14 \mathrm{DAI}$, and $40 \%$ at $21 \mathrm{DAI})$.

Foliar spraying under semi-field conditions. Concentrations of $2.5,5$, and $10 \%$ of the fresh leaf extract of $C$. odorata as well as Bion $50(1,000 \mu \mathrm{g} / \mathrm{ml})$ were tested and disease was assessed at 7 , 14, and 21 DAI (Fig. 3A). All treatments gave reductions in mean lesion lengths compared with the water control at all time points (up to $58 \%$ at $7 \mathrm{DAI}, 41 \%$ at $14 \mathrm{DAI}$, and $30 \%$ at $21 \mathrm{DAI}$ ), except for $5 \%$ extract assessed at 14 and 21 DAI. No differences were seen among the three spraying time points, which were 3,5 , and 7 DBI (Fig. 3B).

For extract of dried leaves of $C$. odorata, concentrations of 1 , 2.5 , and $5 \%$ were tested and disease was assessed at 7, 14, and 21 DAI (Fig. 3C). Reductions of mean lesion lengths (up to 53\%) were observed at 7 DAI for all treatments compared with the water control. At 14 DAI, 2.5 and 5\% extract as well as Bion retained the disease-reducing effect (up to $38 \%$ ), whereas at 21 DAI only $2.5 \%$ extract and Bion reduced disease (up to $34 \%$ ). No differences were observed between the spraying time points (3, 5, and 7 DBI) (Fig. 3D).

Seed soaking under semi-field conditions. The six concentrations of fresh leaf extract of $C$. odorata $(0.5,1,2,2.5,5$, and $10 \%$ ) tested under controlled conditions were also tested under semi-field conditions (Fig. 4A). All concentrations reduced mean lesion lengths compared with the water control at 7 (up to $68 \%$ ) and 21 DAI (up to 59\%), except $1 \%$ at 21 DAI. Three concentrations of $C$. odorata extract made from dried leaves $(1,2.5$, and $5 \%$ ) were also tested with disease assessments at 7,14 , and 21 DAI (Fig. 4B). All treatments reduced mean lesion lengths compared with the water control at all disease assessment time points (up to $37 \%$ at $7 \mathrm{DAI}, 44 \%$ at $14 \mathrm{DAI}$, and $56 \%$ at $21 \mathrm{DAI}$ ), except for $1 \%$ extract at 7 DAI.

Effect of $C$. odorata leaf extract on bacterial blight, blast and brown spot. Foliar spraying under semi-field conditions. All concentrations of leaf extract $(1,2.5,5$, and 10\%) reduced mean lesion lengths of bacterial blight compared with the water control until 30 DAI (up to $50 \%$ at 10 DAI, $34 \%$ at 20 DAI, and $27 \%$ at 30 DAI) (Fig. 5A). Reduction in infected leaf area of blast was observed until 14 DAI only for 1 and $2.5 \%$ extract (up to $45 \%$ at $7 \mathrm{DAI}$, and $43 \%$ at $14 \mathrm{DAI}$ ) (Fig. 5B). No reductions were observed for brown spot (data not shown).

Seed soaking under semi-field conditions. All concentrations of leaf extract $(1,2.5,5$, and $10 \%)$ reduced mean lesion lengths of bacterial blight compared with the water control at 10 (up to $50 \%$ ) and 20 DAI (up to $47 \%$ ), whereas only $2.5 \%$ maintained the effect until 30 DAI (39\%) (Fig. 5C). No disease-reducing effect was seen for blast (data not shown). For brown spot, 5\% extract reduced infected leaf area at $5(57 \%)$ and 10 DAI (28\%), whereas $2.5 \%$ extract only reduced disease until 5 DAI (29\%) (Fig. 5D).

Direct antimicrobial activity. No direct antimicrobial activity of $C$. odorata leaf extract was seen on $R$. solani, $P$. oryzae, $B$. oryzae, and $X$. oryzae pv. oryzae. Indeed, by placing $5 \mathrm{~mm}$ filter paper disks (soaked either in sterile distilled water, in 5 and $10 \%$ filter-sterilized extract, or in cycloheximide at $400 \mu \mathrm{g} / \mathrm{ml}$ ) in front of the actively growing mycelial tips, no inhibition by the plant extract was observed for $R$. solani (Fig. 6A), P. oryzae (Fig.

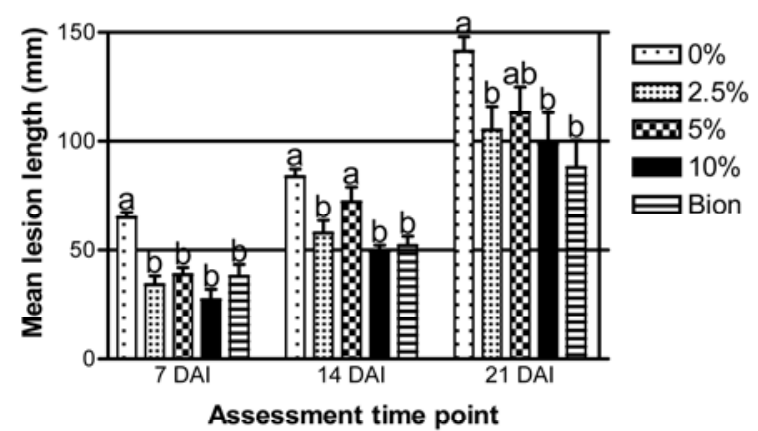

A

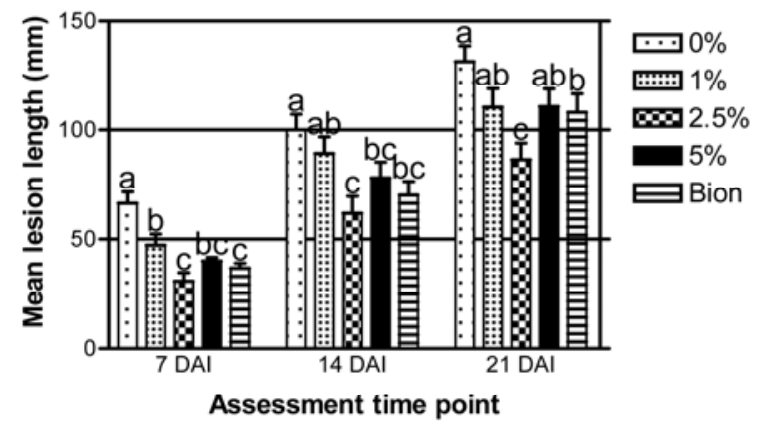

C

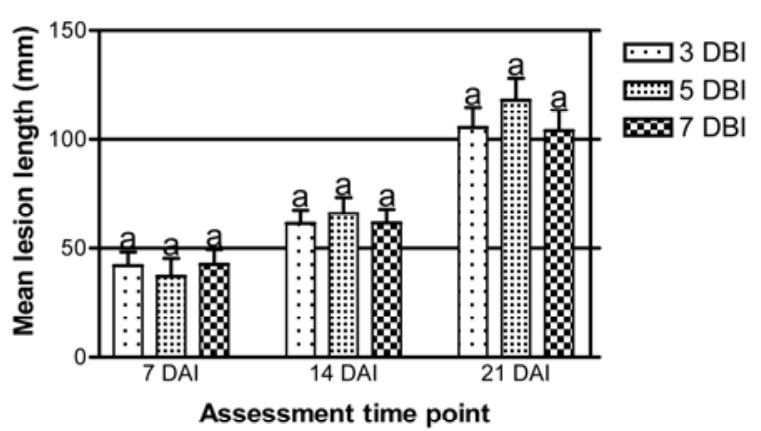

B

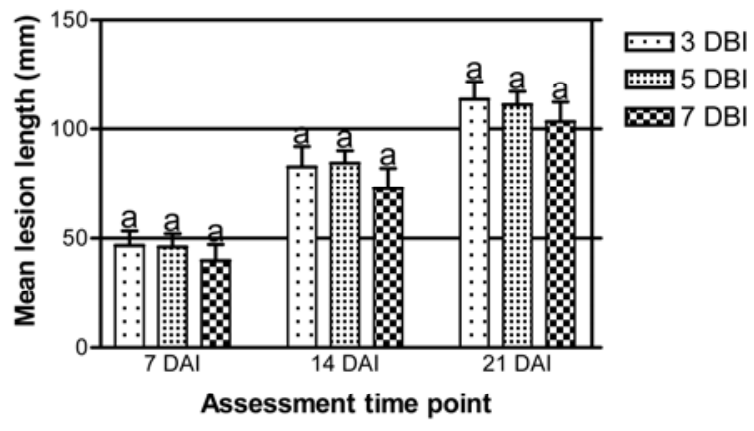

D

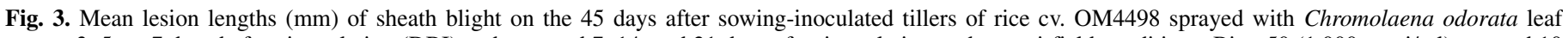

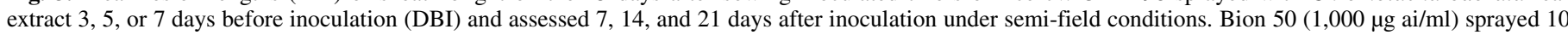

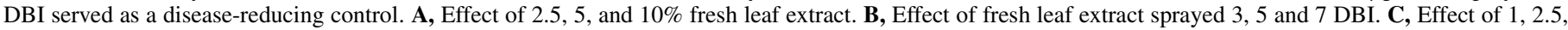

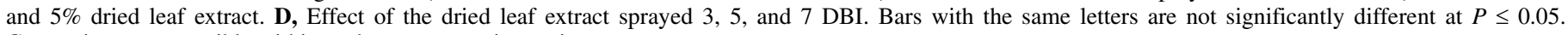
Comparisons are possible within each assessment time point. 
6B), or B. oryzae (Fig. 6C). Furthermore, no effect was seen on conidial germination of $P$. oryzae and $B$. oryzae since no differences in germination were seen between treatment with $10 \%$ extract and treatment with water after soaking the conidia for $12 \mathrm{~h}$ (Fig. 7). Finally, tests for the effect of $10 \%$ extract on the vigor of $X$. oryzae pv. oryzae showed that the number of CFU was the highest for the extract compared with the other treatments (Fig. $6 \mathrm{D}$ to $\mathrm{F})$.

\section{DISCUSSION}

Rice is under constant attack by several diseases and sheath blight is one of the most important. Sclerotia of $R$. solani persist in soil and plant debris and spread through water supply or floods in rice fields, subsequently infecting the sheath part of rice plants at the tillering stage. Therefore, it is difficult to target the pathogen by foliar spray applications with any kind of fungicide. We found that an aqueous extract of the common herbal plant $C$. odorata could reduce lesion length of sheath blight (up to 68\%) as well as severity of other important diseases of rice (up to $45 \%$ for blast, $57 \%$ for brown spot, and $50 \%$ for bacterial blight) using either foliar spraying or seed soaking applications, even though not all treatments were effective (e.g., foliar spraying was not effective against brown spot and seed soaking was not effective against blast). Under semi-field conditions (Figs. 3A and $\mathrm{C}$ and
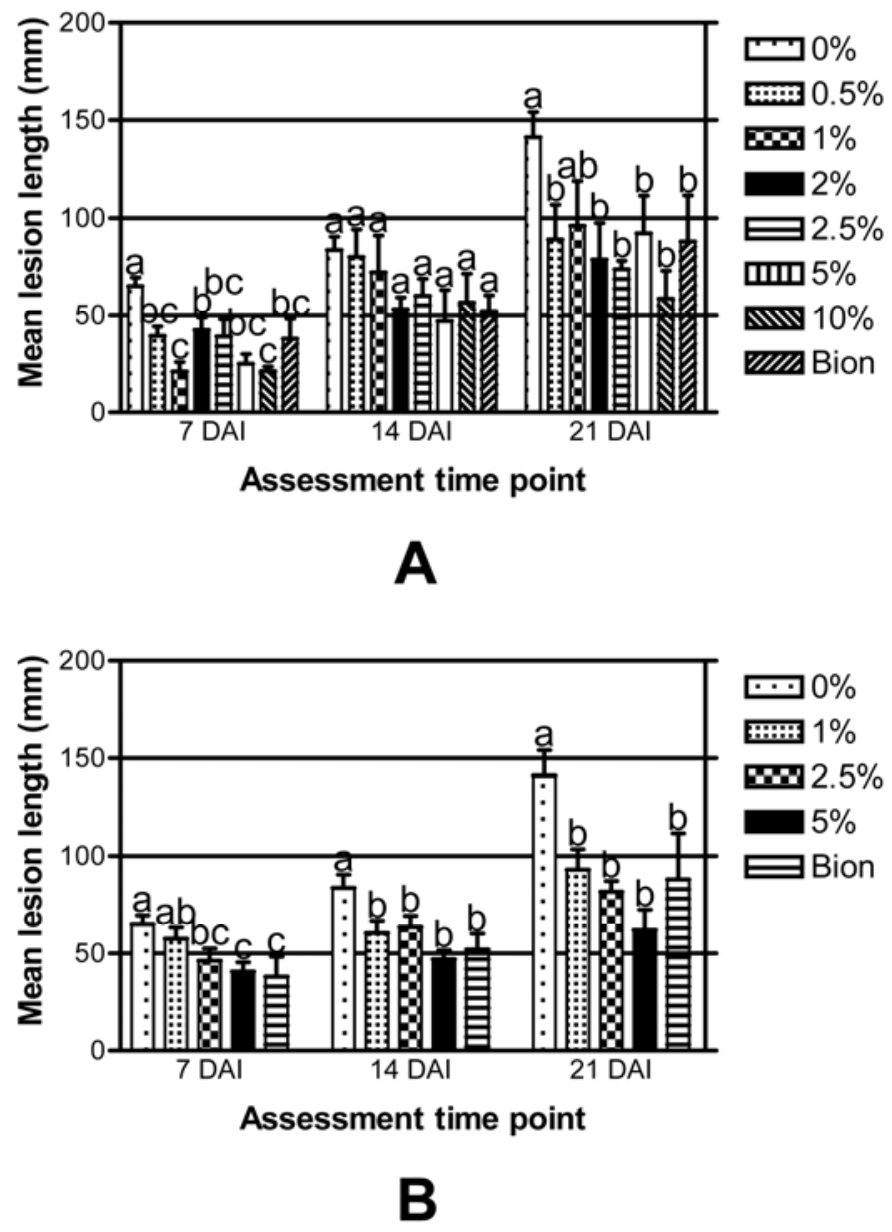

Fig. 4. Mean lesion lengths $(\mathrm{mm})$ of sheath blight on the 45 days after sowinginoculated tillers of rice cv. OM4498 assessed 7, 14, and 21 days after inoculation under semi-field conditions. The rice seeds were soaked in Chromolaena odorata leaf extract. Bion $50(1,000 \mu \mathrm{g}$ ai $/ \mathrm{ml})$ sprayed 10 days before inoculation served as a disease-reducing control. A, Effect of 0.5, 1, 2, $2.5,5$, and $10 \%$ fresh leaf extract. B, Effect of $1,2.5$, and $5 \%$ dried leaf extract. Bars with the same letters are not significantly different at $P \leq 0.05$. Comparisons are possible within each assessment time point.
4), this extract showed an equal or even stronger effect compared with that of Bion 50, which is generally accepted as an inducer of plant resistance, among others against sheath blight (49). Interestingly, the symptom expression of the diseases was reduced following the treatment with the $C$. odorata extract, but disease development was not prevented, which contrasts with most traditional chemical control agents. Attempts to control $R$. solani using plant extracts have previously been made in vitro by, for example, methanol leaf extracts of Petroselinum crispum and Ruta graveolens (44), an ethanol leaf extract of Flourensia spp. (14), and a hexane fraction of Acorus gramineus rhizomes (37). In planta, Kagale et al. (29) showed that foliar spraying with a methanol extract of $D$. metel was able to control rice sheath blight through a direct antimicrobial effect of this extract as well as by induced resistance. Common to these studies is that organic solvent extracts were used as foliar sprays to control $R$. solani, whereas we used an aqueous extract and this extract could be applied as both foliar spray and seed treatment. This is an advantage since such an extract is cheaper and simpler to prepare and easier for farmers to apply compared with the extracts mentioned above. Moreover, C. odorata is an invasive weed, which can be found in many rice-growing regions throughout the tropics.

The extract of $C$. odorata was found to possess a general ability to protect rice against sheath blight. Indeed, extracts from fresh leaves grown in both Vietnam and Denmark were able to reduce disease under controlled conditions. Plants of the same species, but grown under different conditions could vary, for example, in secondary metabolite production and therefore ability to control the disease, but here the active components were maintained in plants grown under different conditions. Furthermore, both fresh and dried leaves of $C$. odorata were able to reduce the disease, showing that the active components of the extract still maintained their effect after drying. Although it is generally not difficult to find fresh leaves of $C$. odorata in Vietnam, using dried leaves potentially represents a useful solution for farmers in areas where the plant is not abundant. Likewise, the extract was able to protect different rice cultivars (OM4498 and Tetep). Cultivar Tetep has been considered as partially resistant to sheath blight $(47,51)$, but it was as susceptible as cv. OM4498 under the experimental conditions in Denmark. Furthermore, the effect of $C$. odorata leaf extract on rice sheath blight was evident under both controlled and semi-field conditions using foliar spraying and seed soaking applications. Generally, we think $2.5 \%$ extract is an optimal concentration because it is a rather low concentration and gave a broad effect on sheath blight as well as the other diseases under both controlled and semi-field conditions by different application methods.

The present investigation clearly demonstrated that $C$. odorata extract possessed the ability to inhibit $R$. solani and other important rice pathogens; therefore, extract of this plant could be a potential candidate for practical disease control in rice fields. As mentioned above, aqueous fresh leaf extract of this plant is styptic and is used as a folk remedy to treat different human diseases via oral application $(6,7)$. Currently, there is no evidence of any harmful effect of this plant on humans and therefore this extract does not appear to pose any threat, though clearly this needs to be tested thoroughly before any widespread use. As $C$. odorata is an invasive weed, farmers can find its leaves around their farms or they can collect leaves from other areas and dry them for storage. Cheese cloth and a grinder (or a mortar and a pestle) are commonly found in all houses. The extract is made at room temperature with only water. This is a farmer-friendly method as the materials are cheap and easily found and the steps are simple to perform.

With respect to application methods, seed soaking is, in general, a very attractive approach because it is more efficient than foliar spraying. Indeed, it is less environmentally dependent, needs smaller volumes of the extract, requires less time and labor 


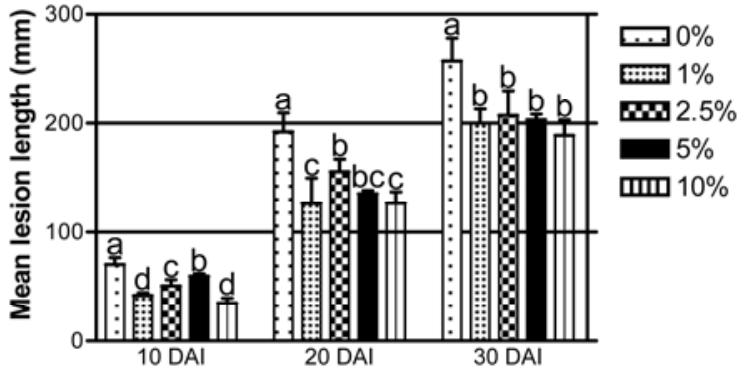

Assessment time point

A

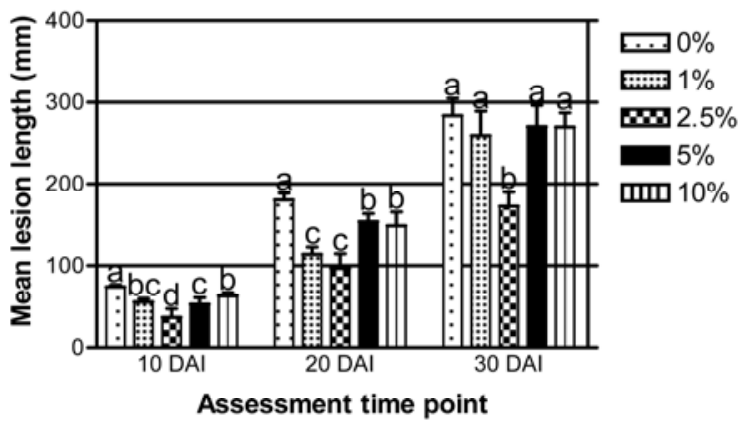

C

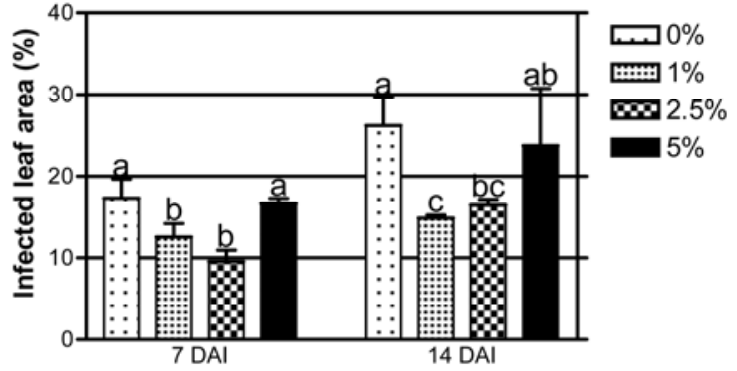

Assessment time point

B

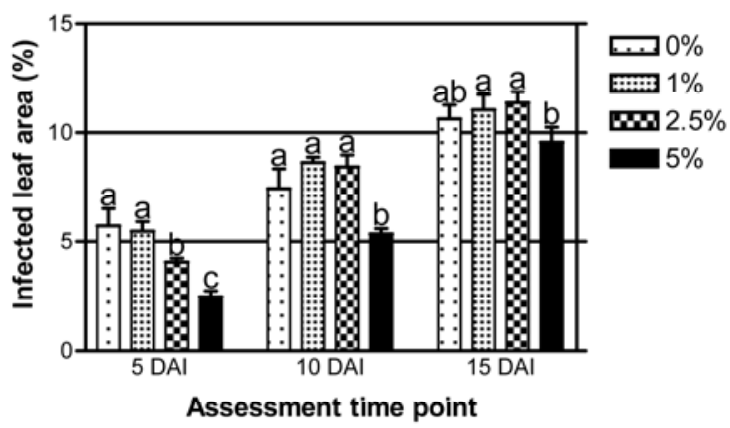

D

Fig. 5. Effect of Chromolaena odorata fresh leaf extract on other important rice diseases under semi-field conditions. A, Mean lesion lengths (mm) of bacterial blight on the 35 days after sowing (DAS)-inoculated leaves of rice cv. Jasmine 85 sprayed with 1, 2.5, 5, or 10\% extract 5 days before inoculation (DBI) and assessed 10, 20, and 30 days after inoculation (DAI). B, Percent infected leaf area of blast on the 20 DAS-inoculated leaves of rice cv. Jasmine 85 sprayed with 1 , 2.5 , or $5 \%$ extract 5 DBI and assessed 7 and 14 DAI. C, Mean lesion lengths $(\mathrm{mm})$ of bacterial blight on the 35 DAS-inoculated leaves of rice cv. Jasmine 85 assessed 10, 20 and 30 DAI. Rice seeds were soaked in 1, 2.5, 5, or 10\% extract. D, Percent infected leaf area of brown spot on the 20 DAS-inoculated leaves of rice cv. OM4498 assessed 5, 10, and 15 DAI. Rice seeds were in 1, 2.5, or 5\% extract. Bars with the same letters are not significantly different at $P \leq 0.05$. Comparisons are possible within each assessment time point.

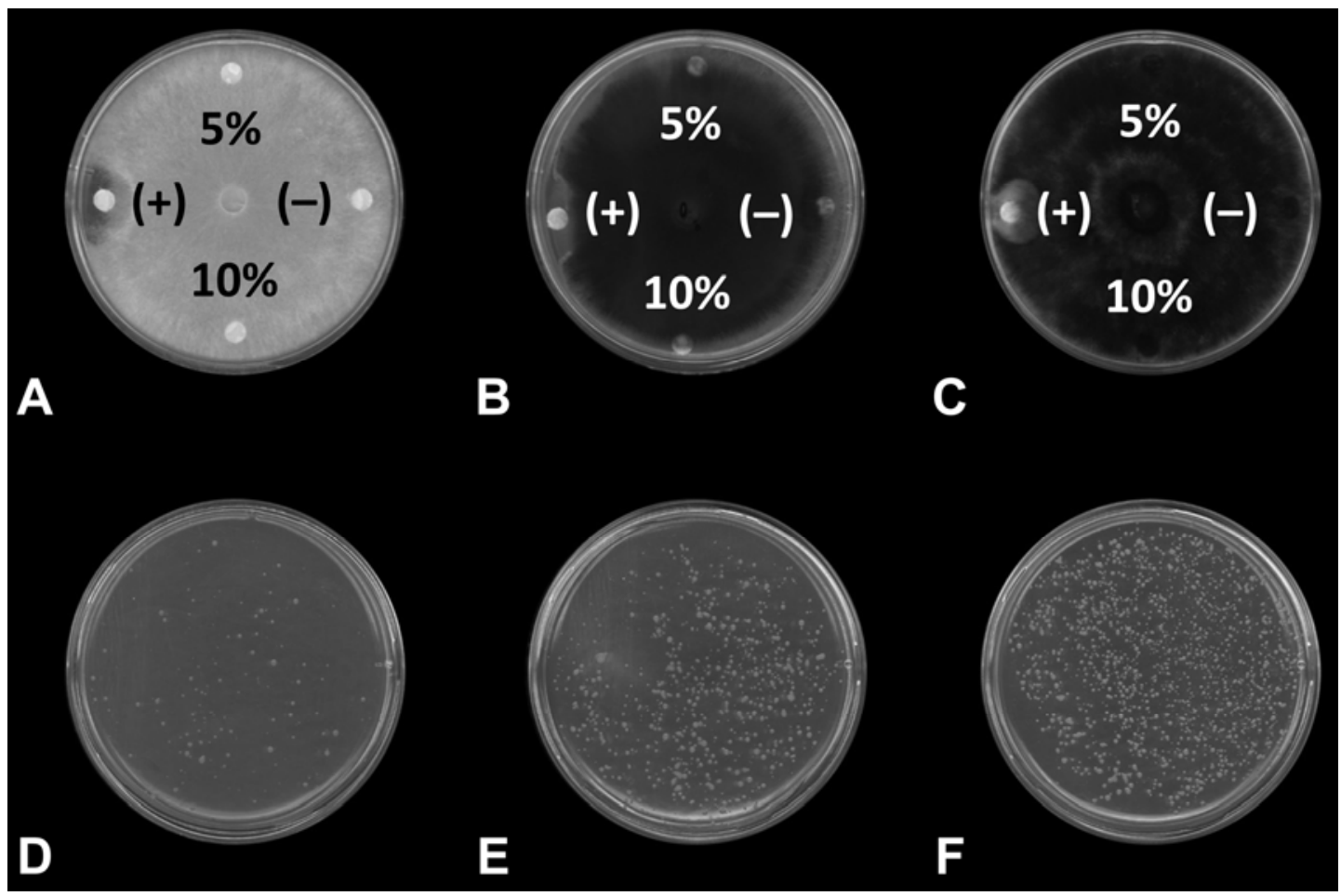

Fig. 6. Tests for direct antimicrobial activity of Chromolaena odorata fresh leaf extract on important rice pathogens. (+) indicates positive control using cycloheximide at $400 \mu \mathrm{g} / \mathrm{ml}$. (-) indicates negative control using sterile distilled water. Pictures taken 3 days after placing filter-paper disks (A, B, and C) and 3 days after plating (D, E, and F). A, Effect of 5 and $10 \%$ extract on the mycelial growth of Rhizoctonia solani. B, Effect of 5 and $10 \%$ extract on the mycelial growth of Pyricularia oryzae. C, Effect of 5 and 10\% extract on the mycelial growth of Bipolaris oryzae. D, Effect of CuSO $\mathrm{C}_{4} \times 5 \mathrm{H}_{2} \mathrm{O}$ at $200 \mathrm{mg} / \mathrm{ml}$ on the cell vigor of Xanthomonas oryzae pv. oryzae (positive control). E, Effect of sterile distilled water on the cell vigor of X. oryzae pv. oryzae (negative control). F, Effect of $10 \%$ extract on the cell vigor of $X$. oryzae pv. oryzae. 
for application, and could have an effect on some seed-transmitted pathogens. Most of the studies in control of rice sheath blight have focused on spraying applications because they mainly employ direct antimicrobial effects. Even when Kagale et al. (29) reported that an extract of $D$. metel induced resistance, they still used foliar sprays. However, it is difficult to achieve an effective control using spray applications, particularly for sheath blight. This is because the sclerotia of the pathogen float on the water surface of rice fields and then attack and cause disease on rice sheaths, so it is very difficult for any control agents to reach the pathogen by foliar spraying, especially when the plants become tall. Moreover, spray application is normally ineffective if it rains right after application. Nevertheless, we tested the effect of foliar spray application because it could be used together with seed soaking application in practical farming in case there is a high disease pressure in rice fields.

Vietnam is one of the largest rice exports in the world. However, the incomes of farmers after each rice season are often still low. This is, among others, due to diseases, which are difficult and expensive to control. Since sheath blight is one of the most serious diseases of rice, use of $C$. odorata extract to control the disease potentially offers a good solution to increase the incomes of farmers. Reduction in expression of disease symptoms is likely to prevent yield loss although the exact link between these in our studies has not been made yet. For example, reductions of sheath blight lesion length after applying $C$. odorata extracts result in healthier and stronger rice plants, which could continue growing and therefore produce seeds. The longer the lesion lengths on rice sheaths, the easier the rice plants to collapse and die. Whereas there are attempts to control $C$. odorata $(4,33,41)$, farmers could use $C$. odorata to control sheath blight and other diseases. Thus,
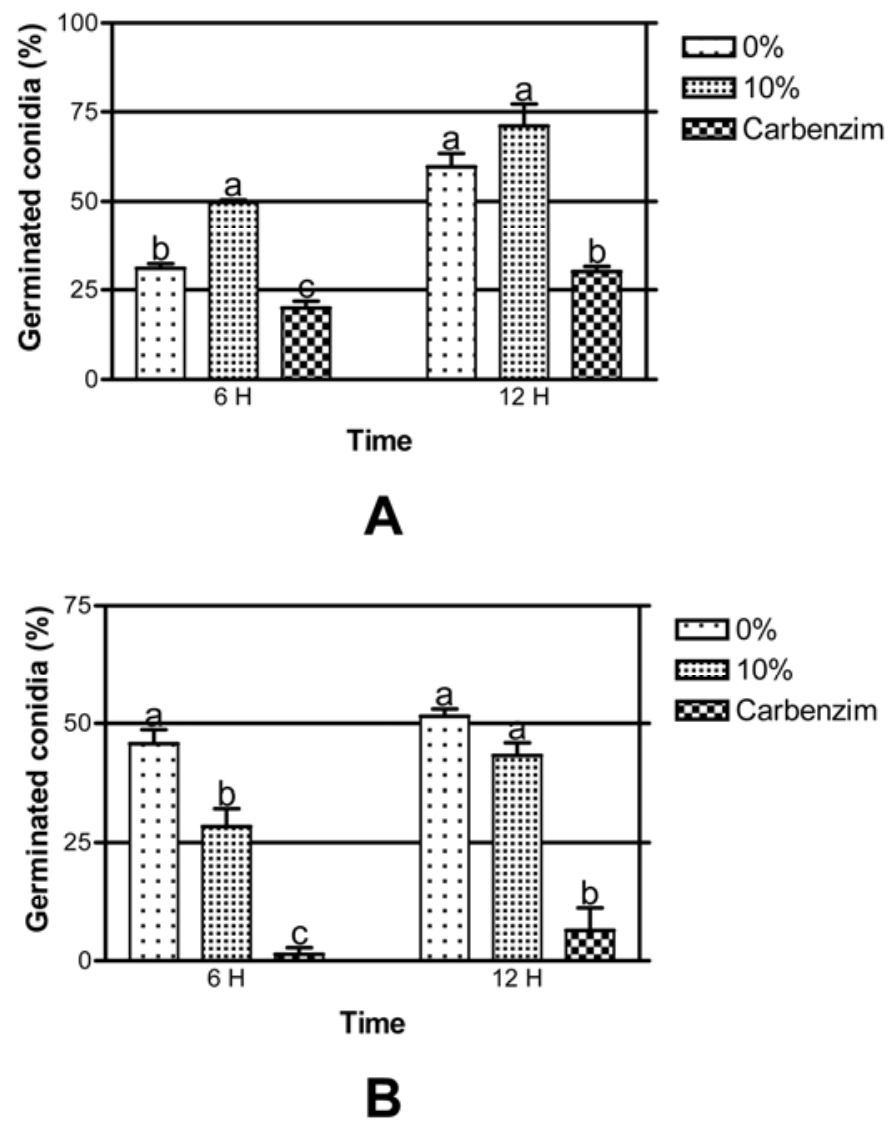

Fig. 7. Test for direct antimicrobial activity of $10 \%$ Chromolaena odorata fresh leaf extract on conidial germination of $\mathbf{A}$, Pyricularia oryzae and $\mathbf{B}$, Bipolaris oryzae. Carbenzim $500 \mathrm{FL}(0.625 \mathrm{mg} / \mathrm{ml})$ served as a positive control. Bars with the same letters are not significantly different at $P \leq 0.05$. Comparisons are possible within each assessment time point. they would achieve a dual advantage, where both diseases, and to some extent, the weed are controlled in a cheap, simple, and ecofriendly way. Because $C$. odorata is present at most of the tropical parts of the world (41), this approach can be applied not only in Vietnam, but also in other tropical countries where rice is an important crop. The efficiency of the extract under field conditions is currently being evaluated.

Although it has previously been shown that extracts of $C$. odorata could inhibit a number of bacteria, protozoa, and fungi in vitro $(26,43,60)$, no direct antimicrobial activity of the aqueous leaf extract of $C$. odorata was observed on $R$. solani in our experiments. However, preliminary investigations concerning the mechanisms underlying the reductions in sheath blight severity suggest that the infection pattern of the pathogen is fundamentally changed (data not shown), indicating that what we observed is not only a reduction in disease severity, but also in infection type, so it is debatable if the reaction is, in fact, susceptible in extracttreated plants. We are currently investigating this subject in detail. Therefore, it could be speculated whether induced resistance (32) was involved in the protection. Interestingly, when the extract was sprayed on the leaf laminae, an effect was observed on $R$. solani causing disease on the leaf sheaths. Furthermore, when the extract was applied to seeds before sowing, the plants could be protected when they were inoculated with the pathogen 45 DAS. This indicates that a very efficient induction of resistance may have taken place here. Indeed, several plant extracts have been reported to be capable of inducing resistance against diseases in plants $(1,24,34)$ and the methanol extract of $D$. metel is an example for rice sheath blight (29). However, it could also be envisaged that other mechanisms might be involved in the protection observed. For example, it could be speculated that application of the extract influenced the microflora on the leaves (by foliar spraying) or endophytes in the seed (by seed soaking) and subsequently stimulated these microorganisms to either produce substances which could be transported in the plant to inhibit the pathogen or induce plant resistance. Moreover, epigenetic regulation of stress responses in plants, where retention of stress memory through histone and DNA modifications is observed $(8,62)$, could also be speculated as a potential mode of action. Thus, application of $C$. odorata extract might have stressed the plants and therefore a number of defense-related genes were up-regulated and this upregulation was retained and protected the plants under subsequent $R$. solani infection. As mentioned above, we are currently investigating the mechanisms involved in the protection exerted by $C$. odorata to determine whether induced resistance or another mechanism accounts for the disease reductions observed. Furthermore, fractionation has commenced to determine the active components of the extract.

\section{ACKNOWLEDGMENTS}

This project is funded by the Danish International Development Agency (Danida), Denmark through the project 104.DAN.8.L.727 "Integrated disease and nutrient management in rice production systems."

\section{LITERATURE CITED}

1. Baysal, O., and Zeller, W. 2004. Extract of Hedera helix induces resistance on apple rootstock M26 similar to acibenzolar-S-methyl against fire blight (Erwinia amylovora). Physiol. Mol. Plant Pathol. 65:305-315.

2. Bej, A. K., Perlin, M., and Atlas, R. M. 1991. Effect of introducing genetically engineered microorganisms on soil microbial community diversity. FEMS Microbiol. Ecol. 86:169-176.

3. Boland, G. J. 1997. Stability analysis for evaluating the influence of environment on chemical and biological control of white mold (Sclerotinia sclerotiorum) of bean. Biol. Control 9:7-14.

4. Brown, J. W., and Zachariades, C. 2007. A new species of Dichrorampha (Lepidoptera:Tortricidae:Grapholitini) from Jamaica: A potential biocontrol agent against Chromolaena odorata (Asteraceae). Proc. Entomol. Soc. Washington 109:938-947. 
5. Chassy, B. M. 2009. Food safety of transgenic rice. Pages 417-455 in: Rice Improvement in the Genomics Era. S. K. Datta, ed. CRC Press, Taylor \& Francis Group, Boca Raton, FL.

6. Chi, V. V. 2002. Dictionary of common plants-Volume 1. Publisher of Science and Technology (Từ điển thực vật thông dụng-Tập 1. Nhà xuất bản khoa học và kỹ thuật). Vietnam.

7. Chi, V. V., and Hop, T. 1999. Useful plants in Vietnam-Volume 1. Publisher of Education (Cây cỏ có ích ở Việt Nam-Tập 1. Nhà xuất bản giáo dục). Vietnam.

8. Chinnusamy, V., and Zhu, J. K. 2009. Epigenetic regulation of stress responses in plants. Curr. Opin. Plant Biol. 12:133-139.

9. Chumthong, A., Kanjanamaneesathian, M., Pengnoo, A., and Wiwattanapatapee, R. 2008. Water-soluble granules containing Bacillus megaterium for biological control of rice sheath blight: Formulation, bacterial viability and efficacy testing. World J. Microbiol. Biotechnol. 24:2499-2507.

10. Collett, D. 1991. Modelling Binary Data. Chapman and Hall, London, UK.

11. Collinge, D. B., Jørgensen, H. J. L., Lund, O. S., and Lyngkjær, M. F. 2010. Engineering pathogen resistance in crop plants: Current trends and future prospects. Annu. Rev. Phytopathol. 48:269-291.

12. Commare, R. R., Nandakumar, R., Kandan, A., Suresh, S., Bharathi, M., Raguchander, T., and Samiyappan, R. 2002. Pseudomonas fluorescens based bio-formulation for the management of sheath blight disease and leaffolder insect in rice. Crop Prot. 21:671-677.

13. Datta, K., and Datta, S. K. 2009. Biotechnological approaches to disease resistance in rice. Pages 179-205 in: Rice Improvement in the Genomics Era. S. K. Datta, ed. CRC Press, Taylor \& Francis Group, Boca Raton, FL.

14. De Rodriguez, D. J., Hernandez-Castillo, D., Angulo-Sanchez, J. L., Rodriguez-Garcia, R., Quintanilla, J. A. V., and Lira-Saldivar, R. H. 2007. Antifungal activity in vitro of Flourensia spp. extracts on Alternaria sp., Rhizoctonia solani, and Fusarium oxysporum. Indian Crop Prod. 25:111116.

15. Duffy, B., Schouten, A., and Raaijmakers, J. M. 2003. Pathogen selfdefense: Mechanisms to counteract microbial antagonism. Annu. Rev. Phytopathol. 41:501-538.

16. Eizenga, G. C., Agrama, H. A., Lee, F. N., and Jia, Y. 2009. Exploring genetic diversity and potential novel disease resistance genes in a collection of rice (Oryza spp.) wild relatives. Genet. Resour. Crop Evol. 56:65-76.

17. Eizenga, G. C., Lee, F. N., and Rutger, J. N. 2002. Screening Oryza species plants for rice sheath blight resistance. Plant Dis. 86:808-812.

18. Fravel, D. R. 2005. Commercialization and implementation of biocontrol. Annu. Rev. Phytopathol. 43:337-359.

19. Fravel, D. R., Rhodes, D. J., and Larkin, R. P. 1999. Production and commercialization of biocontrol products. Pages 365-376 in: Integrated Pest and Disease Management in Greenhouse Crops. R. Albajes, M. L. Gullino, J. C. van Lenteren, and Y. Elad, eds. Kluwer, Dordrecht, The Netherlands.

20. Gitaits, R. D. 1986. Evaluation of chemical control of bacterial disease of tomato. Pages 205-209 in: Methods for Evaluating Pesticides for Control Plant Pathogens. K. D. Hickey, ed. The American Phytopathological Society, St. Paul, MN.

21. Gnanamanickam, S. S., and Mew, T. W. 1990. Biological control of rice diseases (blast and sheath blight) with bacterial antagonists: An alternative strategy for disease management. Pages 87-110 in: Pest Management in Rice. B. T. Grayson, M. B. Green, and L. G. Copping, eds. Elsevier Applied Science, London.

22. Gressel, J., and Valverde, B. E. 2009. A strategy to provide long-term control of weedy rice while mitigating herbicide resistance transgene flow and its potential use for other crops with related weeds. Pest Manag. Sci. 65:723-731.

23. Groth, D., and Lee, F. 2003. Rice diseases. Pages 413-436 in: Rice Origin, History, Technology and Production. C. W. Smith and R. H. Dilday, eds. Wiley, Hoboken, NJ.

24. Guleria, S., and Kumar, A. 2006. Azadirachta indica leaf extract induces resistance in sesame against Alternaria leaf spot disease. J. Cell Mol. Biol. 5:81-86.

25. Herdt, R. W. 2006. Biotechnology in agriculture. Annu. Rev. Environ. Resour. 31:265-295.

26. Irobi, O. N. 1997. Antibiotic properties of ethanol extract of Chromolaena odorata (Asteriaceae). Int. J. Pharmacogn. 35:111-115.

27. Jayaraj, J., Yi, H., Liang, G. H., Muthukrishnan, S., and Velazhahan, R. 2004. Foliar application of Bacillus subtilis AUBS1 reduces sheath blight and triggers defense mechanisms in rice. Zeitschrift für Pflanzenkrankheiten und Pflanzenschutz-J. Plant Dis. Prot. 111:115-125.

28. Kado, C. I. 2009. Horizontal gene transfer: sustaining pathogenicity and optimizing host-pathogen interactions. Mol. Plant Pathol. 10:143-150.

29. Kagale, S., Marimuthu, T., Thayumanavan, B., Nandakumar, R., and Samiyappan, R. 2004. Antimicrobial activity and induction of systemic resistance in rice by leaf extract of Datura metel against Rhizoctonia solani and Xanthomonas oryzae pv. oryzae. Physiol. Mol. Plant Pathol. 65:91-100.

30. Karganilla, A. D., Paris-Natural, M., and Ou, S. H. 1973. A comparative study of culture media for Xanthomonas oryzae. The Philipp. Agric. 57:141-152.

31. Kauffman, H. E., Reddy, A. P. K., Hsieh, S. P. Y., and Merca, S. D. 1973. An improved technique for evaluation of resistance of rice varieties to Xanthomonas oryzae. Plant Dis. Rep. 57:537-541.

32. Kloepper, J. W., Tuzun, S., and Kuc, J. A. 1992. Proposed definitions related to induced disease resistance. Biocontrol Sci. Technol. 2:349-351.

33. Kluge, R. L., and Zachariades, C. 2006. Assessing the damage potential of the stem-boring weevil Lixus aemulus for the biological control of Chromolaena odorata. BioControl 51:547-552.

34. Konstantinidou-Doltsinis, S., Markellou, E., Kasselaki, A. M., Fanouraki, M. N., Koumaki, C. M., Schmitt, A., Liopa-Tsakalidis, A., and Malathrakis, N. E. 2006. Efficacy of Milsana, a formulated plant extract from Reynoutria sachalinensis, against powdery mildew of tomato (Leveillula taurica). BioControl 51:375-392.

35. Koonin, E. V., Makarova, K. S., and Aravind, L. 2001. Horizontal gene transfer in prokaryotes: Quantification and classification. Annu. Rev. Microbiol. 55:709-742.

36. Leach, J. E., Vera Cruz, C. M., Bai, J., and Leung, H. 2001. Pathogen fitness penalty as a predictor of durability of disease resistance genes. Annu. Rev. Phytopathol. 39:187-224.

37. Lee, H. S. 2007. Fungicidal property of active component derived from Acorus gramineus rhizome against phytopathogenic fungi. Bioresource Technol. 98:1324-1328.

38. McDonald, B. A., and Linde, C. 2002. Pathogen population genetics, evolutionary potential and durable resistance. Annu. Rev. Phytopathol. 40:349-379.

39. Mew, T. W., and Rosales, A. M. 1986. Bacterization of rice plants for control of sheath blight caused by Rhizoctonia solani. Phytopathology 76:1260-1264.

40. Mishra, R. P. N., Singh, R. K., Jaiswal, H. K., Kumar, V., and Maurya, S. 2006. Rhizobium-mediated induction of phenolics and plant growth promotion in rice (Oryza sativa L.). Curr. Microbiol. 52:383-389.

41. Muniappan, R., Reddy, G. V. P., and Lai, P. Y. 2005. Distribution and biological control of Chromolaena odorata. Pages 223-233 in: Invasive Plants: Ecological and Agricultural Aspects. Inderjit, ed. Birkhauser Verlag, Switzerland.

42. Narisawa, K., Shimura, M., Usuki, F., Fukuhara, S., and Hashiba, T. 2005. Effects of pathogen density, soil moisture, and soil $\mathrm{pH}$ on biological control of clubroot in Chinese cabbage by Heteroconium chaetospira. Plant Dis. 89:285-290.

43. Ngane, A. N, Etame, R. E., Ndifor, F., Biyiti, L., Zollo, P. H. A., and Bouchet, P. 2006. Antifungal activity of Chromolaena odorata (L.) King \& Robinson (Asteraceae) of Cameroon. Chemotherapy 52:103-106.

44. Ojala, T., Remes, S., Haansuu, P., Vuorela, H., Hiltunen, R., Haahtela, K., and Vuorela, P. 2000. Antimicrobial activity of some coumarin containing herbal plants growing in Finland. J. Ethnopharmacol. 73:299-305.

45. Ou, S. H. 1985. Pages 272-286 in: Rice Diseases. 2nd ed. Commonwealth Mycological Institute, Kew, England.

46. Padaria, J. C., and Singh, A. 2009. Molecular characterization of soil bacteria antagonistic to Rhizoctonia solani, sheath blight of rice. J. Environ. Sci. Heal. B 44:397-402.

47. Park, D. S., Sayler, R. J., Hong, Y. G., Nam, M. H., and Yang, Y. 2008. A method for inoculation and evaluation of rice sheath blight disease. Plant Dis. 92:25-29.

48. Radjacommare, R., Kandan, A., Nandakumar, R., and Samiyappan, R. 2004. Association of the hydrolytic enzyme chitinase against Rhizoctonia solani in rhizobacteria-treated rice plants. J. Phytopathol. 152:365-370.

49. Rohilla, R., Singh, U. S., and Singh, R. L. 2002. Mode of action of acibenzolar-S-methyl against sheath blight of rice, caused by Rhizoctonia solani Kuhn. Pest Manag. Sci. 58:63-69.

50. Rotenberg, D., Joshi, R., Benitez, M. S., Chapin, L. G., Camp, A., Zumpetta, C., Osborne, A., Dick, W. A., and Gardener, B. B. M. 2007. Farm management effects on rhizosphere colonization by native populations of 2,4-diacetylphloroglucinol-producing Pseudomonas spp. and their contributions to crop health. Phytopathology 97:756-766.

51. Sato, H., Ideta, O., Ando, I., Kunihiro, Y., Hirabayashi, H., Iwano, M., Miyasaka, A., Nemoto, H., and Imbe, T. 2004. Mapping QTLs for sheath blight resistance in the rice line WSS2. Breed. Sci. 54:265-271.

52. Shah, J. M., Raghupathy, V., and Veluthambi, K. 2009. Enhanced sheath blight resistance in transgenic rice expressing an endochitinase gene from Trichoderma virens. Biotechnol. Lett. 31:239-244.

53. Shaukat, S. S., and Siddiqui, I. A. 2003. Impact of biocontrol agents Pseudomonas fluorescens $\mathrm{CHA} 0$ and its genetically modified derivatives on the diversity of culturable fungi in the rhizosphere of mungbean. J. Appl. Microbiol. 95:1039-1048. 
54. Shivrain, V. K., Burgos, N. R., Gealy, D. R., Sales, M. A., and Smith, K. L. 2009. Gene flow from weedy red rice (Oryza sativa L.) to cultivated rice and fitness of hybrids. Pest Manag. Sci. 65:1124-1129.

55. Song, X., Liu, L., Wang, Z., and Qiang, S. 2009. Potential gene flow from transgenic rice (Oryza sativa L.) to different weedy rice (Oryza sativa f. spontanea) accessions based on reproductive compatibility. Pest Manag. Sci. 65:862-869.

56. Sridevi, G., Parameswari, C., Sabapathi, N., Raghupathy, V., and Veluthambi, K. 2008. Combined expression of chitinase and $\beta-1,3-$ glucanase genes in indica rice (Oryza sativa L.) enhances resistance against Rhizoctonia solani. Plant Sci. 175:283-290.

57. Stukenbrock, E. H., and McDonald, B. A. 2008. The origins of plant pathogens in agro-ecosystems. Annu. Rev. Phytopathol. 46:75-100.

58. Swaminathan, M. S., and Rao, S. A. 2009. Rice for sustainable food and nutritions security. Pages 375-415 in: Rice Improvement in the Genomics Era. S. K. Datta, ed. CRC Press, Taylor \& Francis Group,
Boca Raton, FL.

59. Tan, W., and Mew, T. W. 2001. Bacterial antagonists against Rhizoctonia solani AG1 in irrigated rice ecosystems. Pages 113-131 in: Exploiting Biodiversity for Sustainable Pest Management. T. W. Mew, E. Borromeo, and B. Hardy, eds. International Rice Research Institute, Manila, Philippines.

60. Vital, P. G., and Rivera, W. L. 2009. Antimicrobial activity and cytotoxicity of Chromolaena odorata (L. f.) King and Robinson and Uncaria perrottetii (A. Rich) Merr. extracts. J. Med. Plants Res. 3:511518.

61. Walters, D., Newton, A., and Lyon, G. 2005. Induced resistance: Helping plants to help themselves. Biologist 52:28-33.

62. Zilberman, D., Gehring, M., Tran, R. K., Ballinger, T., and Henikoff, S. 2006. Genome-wide analysis of Arabidopsis thaliana DNA methylation uncovers an interdependence between methylation and transcription. Nat. Genet. 39:61-69. 